\title{
Contamination, risk, and source apportionment of potentially toxic microelements in river sediments and soil after extreme flooding in the Kolubara River catchment in Western Serbia
}

\author{
Dragan Čakmak ${ }^{1}$ (D) $\cdot$ Veljko Perović $^{1} \cdot$ Svetlana Antić-Mladenović ${ }^{2} \cdot$ Mirjana Kresović $^{2} \cdot$ Elmira Saljnikov $^{3}$. \\ Miroslava Mitrović ${ }^{1}$. Pavle Pavlović ${ }^{1}$
}

Received: 5 October 2017 / Accepted: 14 December 2017 / Published online: 22 December 2017

(C) Springer-Verlag GmbH Germany, part of Springer Nature 2017

\begin{abstract}
Purpose Climate change is contributing to an increase in extreme weather events. This results in a higher river flooding risk, causing a series of environmental disturbances, including potential contamination of agricultural soil. In Serbia, the catastrophic floods of 2014 affected six river basins, including the Kolubara River Basin, as one of the larger sub-catchments of the large regional Sava River Basin, which is characterized by large areas under agricultural cultures, various geological substrates, and different types of industrial pollution. The main aim of this study was to establish the sources of potentially toxic elements in soil and flood sediments and the effect of the flood on their concentrations.

Materials and methods Field sampling was performed immediately after water had receded from the flooded area in May 2014. In total, 36 soil samples and 28 flood sediment samples were collected. After acid digestion $\left(\mathrm{HNO}_{3}\right)$, concentrations of the most frequent potentially toxic elements (PTE) in agricultural production ( $\mathrm{As}, \mathrm{Cd}, \mathrm{Cr}, \mathrm{Cu}, \mathrm{Ni}, \mathrm{Pb}, \mathrm{Zn}$ ) and $\mathrm{Co}$ which are closely related to the geological characteristics of river catchments, were analyzed. The origin, source, and interrelations of microelements, as well as background values of the PTE of the river catchment, the pollution index (Pi), enrichment factor (Ef), and geological index (Igeo), were determined, using statistical methods such as Pearson correlations, principal component analysis (PCA), and multiple linear regression (MLRA).

Results and discussion The content of the hot acid-extractable forms of the elements, PCA, and MLRA revealed a heavy geological influence on microelement content, especially on $\mathrm{Ni}, \mathrm{Cr}$, and $\mathrm{Co}$, while an anthropogenic influence was observed for $\mathrm{Cu}, \mathrm{Zn}$, and $\mathrm{Cd}$ content. This mixed impact was primarily related to mines and their impact on As and $\mathrm{Pb}$ content. The pseudo-total concentrations of all the analyzed elements did not prove to be a danger in the catchment area, except for $\mathrm{Cu}$ in some samples, indicating point-source pollution, and $\mathrm{Ni}$, whose pseudo-total content could be a limiting factor in agricultural production. For the Ef, the Ni content in 59\% soil and $68 \%$ flood sediment samples is classified into influence classes.

Conclusions The similar pseudo-total contents of the elements studied in soil samples and flood sediment and their origin indicate that the long-term soil formation process is subject to periodic flooding in the Kolubara River Basin without any significant
\end{abstract}

Responsible editor: Dong-Mei Zhou

Electronic supplementary material The online version of this article (https://doi.org/10.1007/s11368-017-1904-0) contains supplementary material, which is available to authorized users.

Dragan Čakmak

dragan.cakmak@ibiss.bg.ac.rs

1 Department of Ecology, Institute for Biological Research 'Siniša Stanković', University of Belgrade, Bulevar despota Stefana 142, Belgrade 11060, Serbia
2 Faculty of Agriculture, University of Belgrade, Nemanjina 6, Belgrade 11080, Serbia

3 Soil Science Institute, Teodora Drajzera 7, Belgrade 11000, Serbia 
changes taking place. This implies that floods are not an endangering factor in terms of the contamination of soil by potentially toxic elements in the explored area.

Keywords Flood $\cdot$ Multiple linear regression analysis $\cdot$ Principal component analysis $\cdot$ Potential toxic elements $\cdot$ Sediments $\cdot$ Soil

\section{Introduction}

Potentially toxic elements (PTE), including heavy metals, are usually found in low concentrations in soils and rocks. Sources of PTE are usually considered to be of anthropogenic origin and the degree and extent of pollution have been studied in environmental science, with it being particularly important in agricultural soils because of the quick introduction of PTE into the food chain due to intensive plant production (Adriano 2002). The distribution of PTE in soils is controlled by parent-rock geochemistry, climatic and geomorphologic conditions, the time of weathering exposition, soil texture, living organisms, and anthropogenic inputs, such as industrial pollution and mining, as well as some characteristic activities linked to agricultural production, e.g., manuring and the use of protective measures (Hutchinson and Rothwell 2008; Cakmak et al. 2010; Roca et al. 2012; Cabral Pinto et al. 2014). Concern about the presence and accumulation of these PTE in soil and plants has been ongoing due to their adverse effects on both the environment and human health (des SantosAraujo and Alleoni 2016). Flash floods cause landscape degradation due to the removal of soil and flood material sedimentation, as well as mechanical pollution and water polluted with PTE, resulting in a series of environmental disturbances (Lauer 2008; Milačič et al. 2017). In addition, the content of potentially toxic microelements in flood-related soils changes (Guo et al. 2014), whether they are of anthropogenic (e.g., Martínez-Santos et al. 2015) or geological origin (e.g., Liu et al. 2016). These changes affect agricultural land in river valleys in particular (Du Laing et al. 2009). Soils that are under the direct influence of flood sediments can represent a pollution source in themselves or through interacting with other factors across multiple spatial and temporal scales (Erftemeijer et al. 2012). Therefore, river sediments become an important indicator for characterizing sources of pollution and the anthropogenic impact (Xu et al. 2014).

However, due to the physical and chemical changes which occur during flooding, the content and total form of PTE in sediments cannot be the only measure of their impact on agricultural soils. Hence, it is necessary to establish their background levels and their levels compared to the total PTE content at the sampling sites. In this way, the coefficients and indices obtained give a more realistic picture of pollution and the anthropogenic impact. Besides this, in the wider spatial context, the relationship between certain coefficients can point very clearly to the extent of the impact of certain pollutants (N'guessan et al. 2009). Climate change is contributing to an increase in extreme weather events, including greater intensity storm rainfall, in many parts of the world, leading to higher risks of river flooding (Bates et al. 2008). Since the 1960s, there have been 298 floods in EU countries, accounting for $12 \%$ of all global floods (Green et al. 2013). In Serbia, from 1915 to 2013, 848 flash floods were registered (Petrović et al. 2014), with one of the biggest occurring in 2014, covering six river catchments: the Danube, Sava, Velika Morava, Western Morava, Drina, and Kolubara. Over 200-mm precipitation fell between May 15 and 24, more than the 3-month precipitation average for that time of year, which resulted in 482,700 ha of land flooding. After the water receded, flood sediment had to be removed from $335,400 \mathrm{~m}^{2}$ of land (Serbian Government Report on Floods 2014).

In this regard, this study aimed to evaluate the possible effects of the 2014 flooding on environmental disturbances and arable soil pollution in the Kolubara River Basin by measuring and analyzing the quantities of hot acid-extractable forms of potentially toxic elements in soil and flooded sediments immediately after flood water receded. The collected samples were analyzed for the hot acid-extractable forms of potentially toxic elements for those elements that most often represent an endangering factor in agricultural production (As, $\mathrm{Cd}, \mathrm{Cr}, \mathrm{Cu}, \mathrm{Ni}, \mathrm{Pb}, \mathrm{Zn}$ ) and Co which is closely related to the geological characteristics of the river catchment. So as to determine the degree of pollution and the possible environmental impact of flooding, background values of potentially toxic metals and pollution indicators were determined: the pollution index (Pi), enrichment factor (Ef), and geoaccumulation index (Igeo), only for flood sediments that indicate the degree of pollution in relation to national legal norms, the natural background of certain harmful microelements, and the degree of contamination of the sediments themselves. For data processing, the Pearson correlation, principal component analysis (PCA), and multiple linear regression (MLR) analyses were applied.

\section{Materials and methods}

\subsection{Study area}

The Kolubara River (127 km long) flows into the Sava River, which is part of the Black Sea Basin via the Danube. The Kolubara Basin covers $3618.6 \mathrm{~km}^{2}$ between $44^{\circ} 04^{\prime}$ and $44^{\circ}$ 
$39^{\prime} \mathrm{N}$ and $19^{\circ} 34^{\prime}$ and $20^{\circ} 34^{\prime} \mathrm{E}$ (Fig. 1), its boundaries coincide with the boundaries of the Jadar block terrane, and it was geologically very active in the past. In terms of geomorphological classes in the Kolubara River Basin, sands, sandy clays, sandy limestones, and conglomerates are found over half the area, while somewhat less common are marlstones, marly limestones, micaceous sandstones, clayey sandstones, and clays. These forms of geological deposits are found in the valley region of the Kolubara Basin. As opposed to the lowerlying areas of the catchment, its western and southern edges are characterized by massive limestone with flows of diabasehornstone formations as well as sections of serpentinite. On the eastern edge of the catchment, there is more pronounced fragmentation of the geological formations with a large proportion of marlstone, clayey schist sandstones, diabasehornstone formations, harzburgite, lherzolite, and serpentinite The characteristic Jurassic formations of this belt of diabasehornstone formations with basic and ultrabasic rocks are the main sources of metallic minerals (Geolis 2010). The diversity of the geological substrate and its intermixing conditioned the mountains, such as Povlen, Maljen, and Rudnik, on the edge of the basin. They abound in $\mathrm{Pb}, \mathrm{Zn}$, and $\mathrm{Cu}$ ore deposits near ultramafic rocks, which caused high $\mathrm{Ni}, \mathrm{Cr}$, and Co concentrations (Anderson et al. 1973; Antić-Mladenović et al. 2017), as well as deposits of lignite in the catchment area (Filipović 2005). The effect of such a geological substrate on soil is pronounced due to water erosion, with $30.44 \%$ of the Kolubara River Basin under the influence of moderate and very strong erosion processes (Belanovic-Simic et al. 2013). The soil cover here is mainly Stagnosol and Fluvisol in lower areas, while Cambisols are mainly found in the intrazones between Fluvisol and Stagnosol. Along the edges of the Basin, where altitude increases, there are undeveloped
Leptosols and Regosols (WRB 2006; Mrvić et al. 2013; Pavlović et al. 2017). The climate of this area is characterized as continental. The amount of precipitation in the Kolubara Basin is similar to the Central European and Danubian region with a mean annual rainfall of less than $700 \mathrm{~mm}$ in the lower parts of the Kolubara and Tamnava basins. As altitude increases, mean annual precipitation rises to more than $900 \mathrm{~mm}$ and even over $1000 \mathrm{~mm}$ (Đukanović 2000).

\subsection{Sampling}

Immediately after the floodwater had receded, samples of arable soil were collected at certain distances from the riverbed depending on the flood wave, with the sampling points being on the boundary of this wave. A total of 445 samples (274 soil and 171 flood sediment) were taken from the entire flooded area in Serbia and their basic fertility parameters (soil acidity, percentage of $\mathrm{CaCO}_{3}$ and organic matter, and content of available potassium and phosphorus) and content of PTE were analyzed. Out of these samples, 36 soil samples and 28 flood sediment samples were taken from the Kolubara River Basin and the levels of some PTE they contained are presented in this study (Fig. 1 and Table S1 (Electronic Supplementary Material)). The flood sediment was sampled at a depth corresponding to the thickness of the sediment layers (the maximum thickness of the sediment was $30 \mathrm{~cm}$ ). The soil samples were taken directly below the flood sediment layer.

\subsection{Analytical procedures}

After sampling, samples were air-dried, ground, and sieved through a 2-mm mesh. The following analyses were performed: the content of hot acid-extractable forms of PTE (As, Cd, Co,
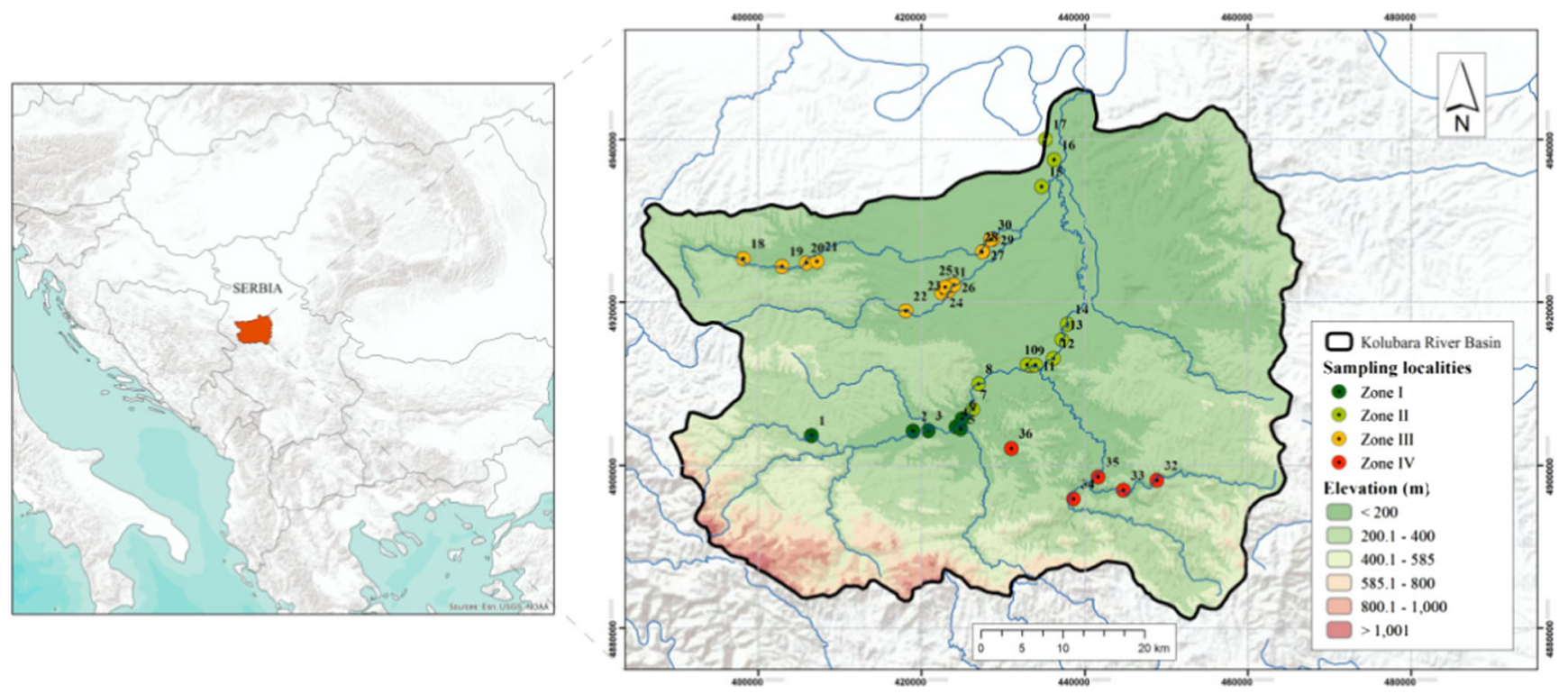

Fig. 1 Sampling localities/sites in the Kolubara River Basin catchment 
$\mathrm{Cr}, \mathrm{Cu}, \mathrm{Ni}, \mathrm{Pb}$, and $\mathrm{Zn}$ ) in soil and flood sediment was determined with an ICAP 6300 optical emission spectrometer (Thermo Electron Corporation, Cambridge, UK) after digestion with nitric acid $\left(\mathrm{HNO}_{3}, 65 \%\right)+$ hydrogen peroxide $\left(\mathrm{H}_{2} \mathrm{O}_{2}\right.$, 30\%) (US EPA Method 3050B, 1996). In 250-mL digestion vessels, $10 \mathrm{~mL} \mathrm{HNO}_{3}$ was added to a 2-g sample, heated to $95^{\circ} \mathrm{C}$, and refluxed. After cooling, $5 \mathrm{~mL}$ of concentrated $\mathrm{HNO}_{3}$ was added and the cover was replaced and it was refluxed for $30 \mathrm{~min}$. If brown fumes were generated, indicating oxidation of the sample by $\mathrm{HNO}_{3}$, this step was repeated (with the addition of $5 \mathrm{~mL}$ of concentrated $\mathrm{HNO}_{3}$ ) until no brown fumes were given off, indicating a complete reaction with $\mathrm{HNO}_{3}$. After boiling for $2 \mathrm{~h}, 2 \mathrm{~mL}$ of water and $3 \mathrm{~mL}$ of $30 \% \mathrm{H}_{2} \mathrm{O}_{2}$ were added. The vessel was covered with a watch glass and returned to the heat source for warming and to start the peroxide reaction. After cooling, it was diluted to $100 \mathrm{~mL}$ with water. Particulates in the digestate were then removed by filtration. For result verification, the referent soil (ERM-CC141 loam soil, Belgium) was analyzed. The recovery ranged from 89 to $112 \%$. Detection limits for the elements were as follows: $0.6436 \mathrm{mg} \mathrm{kg}^{-1}$ (As), $0.0326 \mathrm{mg} \mathrm{kg}^{-1}$ (Co) $0.0166 \mathrm{mg} \mathrm{kg}^{-1}$ (Cd), $0.2897 \mathrm{mg} \mathrm{kg}^{-1}(\mathrm{Cr}), 2.3233 \mathrm{mg} \mathrm{kg}^{-1}(\mathrm{Cu})$, $0.2239 \mathrm{mg} \mathrm{kg}^{-1}(\mathrm{Ni}), 2.8597 \mathrm{mg} \mathrm{kg}^{-1}(\mathrm{~Pb}), 8.5106 \mathrm{mg} \mathrm{kg}^{-1}$ ( $\mathrm{Zn})$, and $81.4905 \mathrm{mg} \mathrm{kg}^{-1}(\mathrm{Fe})$. For each element, the relative standard deviation (RSD) was lower than 5\%.

\subsection{Indicators of soil and sediment pollution with potentially toxic microelements (PTE)}

The pollution level for a given PTE was evaluated with the Pi, using:

$\mathrm{Pi}=\frac{\mathrm{Ci}}{\mathrm{Si}}$

where $\mathrm{Pi}$ is the pollution index, $\mathrm{Ci}$ the metal concentration in the sample, and $\mathrm{Si}$ the reference value (Regulation of the Government of the Republic of Serbia, SG RS88/2010 pp. 226-231, 2010): Pi pollution class: I Clean, 0-1; II Slightly polluted, 1-2; III Moderately polluted, 2-4; IV Heavily polluted, 4-6; and V Extremely polluted, > 6 (Cao et al. 2013).

The Ef of PTE were calculated to assess quantitatively the contribution of anthropogenic sources to those concentrations observed in surface soils. The following equation was used:

$\mathrm{Ef}=\frac{\mathrm{Ci} / \mathrm{Cr}}{\mathrm{Bi} / \mathrm{Br}}$

where $\mathrm{Ci}$ and $\mathrm{Cr}$ are the target metal and reference metal $(\mathrm{Fe})$ concentrations in the soil sample and $\mathrm{Bi}$ and $\mathrm{Br}$ the target metal and reference metal $(\mathrm{Fe})$ background concentrations in the same region. Iron has commonly been used as a reference metal due to its geochemical characteristics (Summer et al.
Table 1 Percentage of PTE sample that exceeds MAC in its content

\begin{tabular}{|c|c|c|c|c|c|c|c|}
\hline Elements & As & $\mathrm{Cd}$ & $\mathrm{Cr}$ & $\mathrm{Cu}$ & $\mathrm{Ni}$ & $\mathrm{Pb}$ & $\mathrm{Zn}$ \\
\hline \multicolumn{8}{|l|}{$\mathrm{mg} \mathrm{kg}^{-1}$} \\
\hline $\mathrm{MAC}^{\mathrm{a}}$ & 25 & 3 & 100 & 100 & 50 & 100 & 300 \\
\hline \multicolumn{8}{|c|}{ Kolubara - samples above MAC \% } \\
\hline Soil & 0.00 & 0.00 & 15.38 & 2.85 & 65.38 & 0.00 & 0.00 \\
\hline Flood sediments & 0.00 & 0.00 & 21.43 & 3.60 & 48.57 & 0.00 & 0.0 \\
\hline
\end{tabular}

${ }^{\mathrm{a}}$ Maximal allowed concentrations (SG RS 23/94, pp. 553-554)

1996; Schiff and Weisberg 1999; Sterckeman et al. 2002; N'guessan et al. 2009; Giri et al. 2017). In our study, using Fe was justified due to the significant impact of deposits of lead ore and serpentinite rocks in the study area which naturally contain high levels of iron (Brooks 1987; Adriano 2002; Massoura et al. 2006; Alexander et al. 2007), as is confirmed by the highly significant correlation with $\mathrm{Co}, \mathrm{As}$, and $\mathrm{Pb}$ in the flood sediments. Ef classification is as follows: I No influence, up to 1; II Minor influence, 1-3; III Moderate influence, 3-5; Moderate to severe influence, 5-10; IV Severe influence, 10-25; V Very severe influence, 25-50; and VI Extremely influence, 50-100 (Guo et al. 2014).

The arithmetical median method was used to calculate the background concentrations (MAD - median of absolute deviations from data median), where a log-transformed modification was performed for $\mathrm{Cr}$ and $\mathrm{Ni}$ due to the dispersion of the results (Reimann et al. 2005; Mrvić et al. 2011). The reference metal for calculating this factor was Fe (Guo et al. 2014).

The Igeo was calculated to evaluate sediment pollution, using:

Igeo $=\log _{2} \mathrm{Ci} / 1.5 \mathrm{bi}$

where $\mathrm{Ci}$ is the concentration of element $i$ and bi the geochemical background value. The factor 1.5 is incorporated in the equation for possible variations in the background data due to the lithogenic effect (Reddy et al. 2004; N'guessan et al. 2009). Igeo pollution classes are as follows: I Unpolluted, < 0 ; II Unpolluted to moderately polluted, 0-1; III Moderately polluted, 1-2; IV Moderately to strongly polluted, 2-3; V Strongly severe polluted, 3-4; and VI Strongly to extremely polluted, 4-5 (Yin et al. 2013).

\subsection{Statistical analyses}

In order to define the spatial impact of PTE in the Kolubara Basin, it was divided into four zones: the first (I) is the upper course of the Kolubara (samples 1-7); the second (II) the lower course of the Kolubara (samples 8-17); the third (III) the subbasin of the Tamnava and Ub rivers (samples 18-31) in the south-western part of the Basin; and the fourth (IV) the River Ljig in the south-western part of the catchment (samples 32-36). 
Table 2 Percentage of samples exceeding certain limit values of individual indexes and factors

\begin{tabular}{|c|c|c|c|c|c|c|c|c|c|c|c|c|c|c|c|c|}
\hline \multirow{2}{*}{$\frac{\text { Class }}{\mathrm{Pi}}$} & \multicolumn{8}{|l|}{ Soil } & \multicolumn{8}{|c|}{ Flood sediments } \\
\hline & As & $\mathrm{Cd}$ & $\mathrm{Cr}$ & Co & $\mathrm{Cu}$ & $\mathrm{Ni}$ & $\mathrm{Pb}$ & $\mathrm{Zn}$ & As & $\mathrm{Cd}$ & $\mathrm{Cr}$ & Co & $\mathrm{Cu}$ & $\mathrm{Ni}$ & $\mathrm{Pb}$ & $\mathrm{Zn}$ \\
\hline I & 100 & 94 & 86 & 3 & 97 & 44 & 100 & 100 & 100 & 79 & 86 & 3 & 92 & 32 & 100 & 96 \\
\hline II & 0 & 3 & 14 & 94 & 0 & 22 & 0 & 0 & 0 & 17 & 14 & 92 & 4 & 25 & 0 & 4 \\
\hline III & 0 & 3 & 0 & 3 & 0 & 22 & 0 & 0 & 0 & 4 & 0 & 4 & 0 & 29 & 0 & 0 \\
\hline IV & 0 & 0 & 0 & 0 & 3 & 11 & 0 & 0 & 0 & 0 & 0 & 0 & 3.6 & 14 & 0 & 0 \\
\hline Ef & As & $\mathrm{Cd}$ & $\mathrm{Cr}$ & $\mathrm{Co}$ & $\mathrm{Cu}$ & $\mathrm{Ni}$ & $\mathrm{Pb}$ & $\mathrm{Zn}$ & As & $\mathrm{Cd}$ & $\mathrm{Cr}$ & Co & $\mathrm{Cu}$ & $\mathrm{Ni}$ & $\mathrm{Pb}$ & $\mathrm{Zn}$ \\
\hline I & 69 & 75 & 50 & 11 & 53 & 42 & 97 & 8 & 71 & 0 & 46 & 21 & 64 & 32 & 100 & 64 \\
\hline II & 31 & 22 & 44 & 89 & 44 & 39 & 3 & 89 & 29 & 89 & 50 & 79 & 32 & 54 & 0 & 32 \\
\hline III & 0 & 0 & 6 & 0 & 0 & 14 & 0 & 3 & 0 & 7 & 3.6 & 0 & 0 & 14 & 0 & 4 \\
\hline IV & 0 & 3 & 0 & 0 & 0 & 6 & 0 & 0 & 0 & 4 & 0 & 0 & 4 & 0 & 0 & 0 \\
\hline V & 0 & 0 & 0 & 0 & 3 & 0 & 0 & 0 & 0 & 0 & 0 & 0 & 0 & 0 & 0 & 0 \\
\hline Igeo & & & & & & & & & As & $\mathrm{Cd}$ & $\mathrm{Cr}$ & Co & $\mathrm{Cu}$ & $\mathrm{Ni}$ & $\mathrm{Pb}$ & $\mathrm{Zn}$ \\
\hline I & & & & & & & & & 100 & 71 & 89 & 100 & 93 & 64 & 100 & 93 \\
\hline II & & & & & & & & & 0 & 25 & 11 & 0 & 4 & 32 & 0 & 7 \\
\hline III & & & & & & & & & 0 & 4 & 0 & 0 & 4 & 4 & 0 & 0 \\
\hline
\end{tabular}

PCA was used to determine the pollution sources more precisely by reducing the total set of PTE data to smaller sets of independent variables. In doing so, clusters were defined which indirectly pointed to the origin of the individual analyzed elements. The absolute principal scores obtained from
PCA for each of the individual factors were analyzed by multiple linear regression analysis (MLRA) as independent factors compared to the analyzed individual elements as dependent factors, and as such, the percentage proportion of the factors and the origin of each of the elements were obtained.

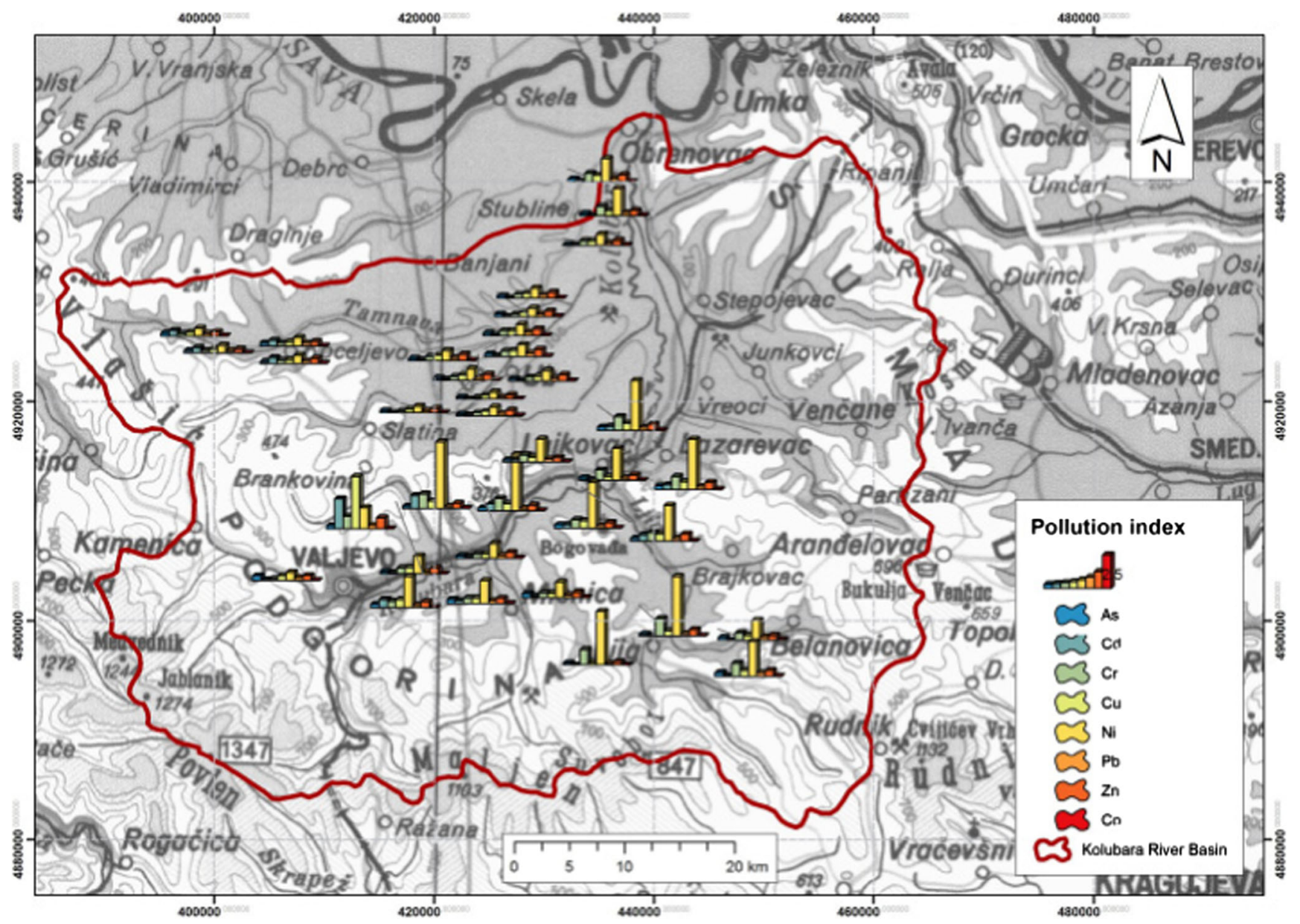

Fig. 2 Pollution index for soil 
Statistical analyses (Pearson correlation, PCA, and MLRA) were performed with SPSS version 20 software (SPSS, v21). Pearson correlation coefficients are given in Table S3 (Electronic Supplementary Material).

\section{Results}

\subsection{Pollution classes}

The PTE whose concentrations exceeded the maximum allowed concentration (MAC) (Regulation of the Ministry of Agriculture and Water Management of the Republic of Serbia, 1994) in soil and sediment were sequenced as follows: $\mathrm{Ni}>\mathrm{Cr}$ $>\mathrm{Cu}$, according to the number of samples, while $\mathrm{As}, \mathrm{Cu}, \mathrm{Pb}$, and $\mathrm{Zn}$ did not exceed the MAC (Table 1). Spatially, the highest $\mathrm{Ni}, \mathrm{Cr}$, and $\mathrm{Co}$ concentrations were observed in the south-eastern part of the catchment, at the confluence and downstream of the River Ljig. For $\mathrm{Cu}$ and $\mathrm{Zn}$, spotted pollution was observed in sample 2 (zone I), while slightly higher $\mathrm{Pb}$ and As levels were found in the upper Kolubara Basin in Table S1 (Electronic Supplementary Material).
$\mathrm{Pi}$ values for $\mathrm{As}, \mathrm{Pb}$, and $\mathrm{Zn}$ in $100 \%$ of samples, for $\mathrm{Cu}$ in $97 \%$, and for $\mathrm{Cd}$ in $94 \%$ classify the soils as clean (unpolluted). For Co, $94 \%$ of samples were slightly polluted, while $3 \%$ were clean and $3 \%$ moderately polluted. For $\mathrm{Cr}, 86 \%$ was classed as clean, while the remainder was slightly polluted (Table 2). Nickel showed the lowest percentage of samples in the first class (44\%), while $11 \%$ of samples were classed as heavily polluted (Table 2 ).

In flood sediments, a certain decrease in the percentage of "unpolluted" samples was found for $\mathrm{Zn}$ and especially for $\mathrm{Cd}$ where an increase in those classed as slightly polluted (17\%) was observed. For $\mathrm{Ni}$, a lower percentage of soil (32\%) in the unpolluted class was observed, where the other classes characterizing contaminated soils increased proportionately (Table 2).

The spatial distribution of soils according to Pi values for all the elements in the Kolubara catchment coincides with pseudo-total content distribution in Fig. 2 and Table S1 (Electronic Supplementary Material). It indicates elevated $\mathrm{Co}, \mathrm{Cr}$, and Ni levels in zones I, II, and IV. Elevated values for $\mathrm{Cd}, \mathrm{Cu}$, and $\mathrm{Zn}$ were found around Valjevo, while for As and $\mathrm{Pb}$, greater $\mathrm{Pi}$ values were found upstream (Fig. 3).

According to the enrichment factor, the percentage of samples in the lowest category (no influence) ranged from $8 \%$ for

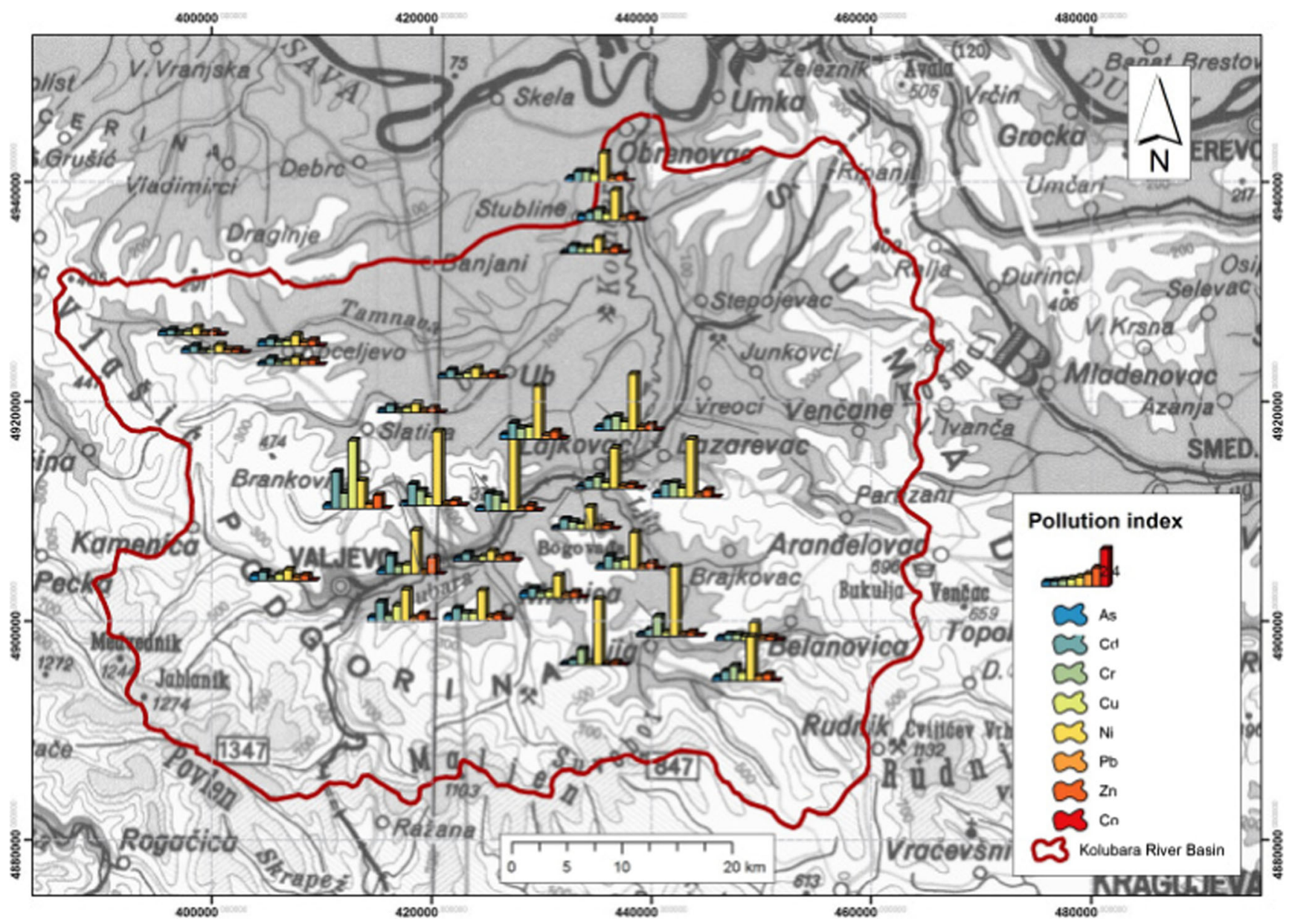

Fig. 3 Pollution index for flood sediment 
$\mathrm{Zn}$ to $97 \%$ for $\mathrm{Pb}$. For $\mathrm{Ni}$, the highest percentages were in the moderate and moderately severe influence classes (Table 2). In flooded sediments, some changes were observed, with the percentage of the lowest category decreasing for $\mathrm{Cr}$ and especially $\mathrm{Ni}$ and $\mathrm{Cd}$. However, for $\mathrm{Zn}$ and $\mathrm{Pb}$, there was a certain increase in the percentage of the first class (Table 2). The spatial distribution of $\mathrm{Ef}$ for particular elements indicates that the highest values of $\mathrm{Cd}$ were found downstream of Valjevo, in the zone of the Kolubara itself for $\mathrm{Cu}$, in the south-eastern part of the Basin and the lower Kolubara River for $\mathrm{Cr}$, Ni, and Co (Fig. 4), and in the upper stream of the Basin for As and $\mathrm{Pb}$. The Ef values for soil and flood sediment generally coincide in spatial terms (Figs. 4 and 5).

The Igeo for $\mathrm{As}, \mathrm{Pb}$, and Co classifies all sediment samples in the same unpolluted category (Table 2). The percentage of samples in this category is sequenced as follows: $\mathrm{Cu}=\mathrm{Zn}>\mathrm{Cr}>\mathrm{Cd}$ $>\mathrm{Ni}$.

\subsection{Pollution sources}

In the PCA of soil and flood sediment, three components were derived, explaining 87 and $84.13 \%$ of the variance, respectively. The first component with $42.29 \%$ variance for soil and $41.23 \%$ for sediment indicates the common origin of $\mathrm{Ni}, \mathrm{Co}$, and $\mathrm{Cr}$ in the samples analyzed, i.e., a prevailing geological origin, while the second component with $29.35 \%$ for soil and $28.39 \%$ for sediment indicates $\mathrm{Cu}, \mathrm{Zn}$, and $\mathrm{Cd}$ are of predominantly anthropogenic origin. The third component explaining 14.40 and $14.06 \%$ respectively of the total variance reveals the mixed origin of $\mathrm{As}$ and $\mathrm{Pb}$ (i.e., both geological and anthropogenic) with the influence of natural deposits of $\mathrm{Pb}$ ore and satellite As on the peripheral mountains of the basin in Figs. 6 and 7 and Table S2 (Electronic Supplementary Material).

In terms of spatial distribution, the influence of $\mathrm{Cr}$, $\mathrm{Ni}$, and $\mathrm{Co}$ in the soil was mostly seen in the downstream section of the River Kolubara (zone II) and in the southeastern part of the Basin, near the River Ljig (zone IV). That of $\mathrm{Cu}, \mathrm{Zn}$, and $\mathrm{Cd}$ was observed in the area of the upper course of the Kolubara (zone I), partially in the downstream section of the Kolubara (zone II), and in the western part of the Basin along the River Tamnava (zone III). Point-source pollution with the highest value in PC2

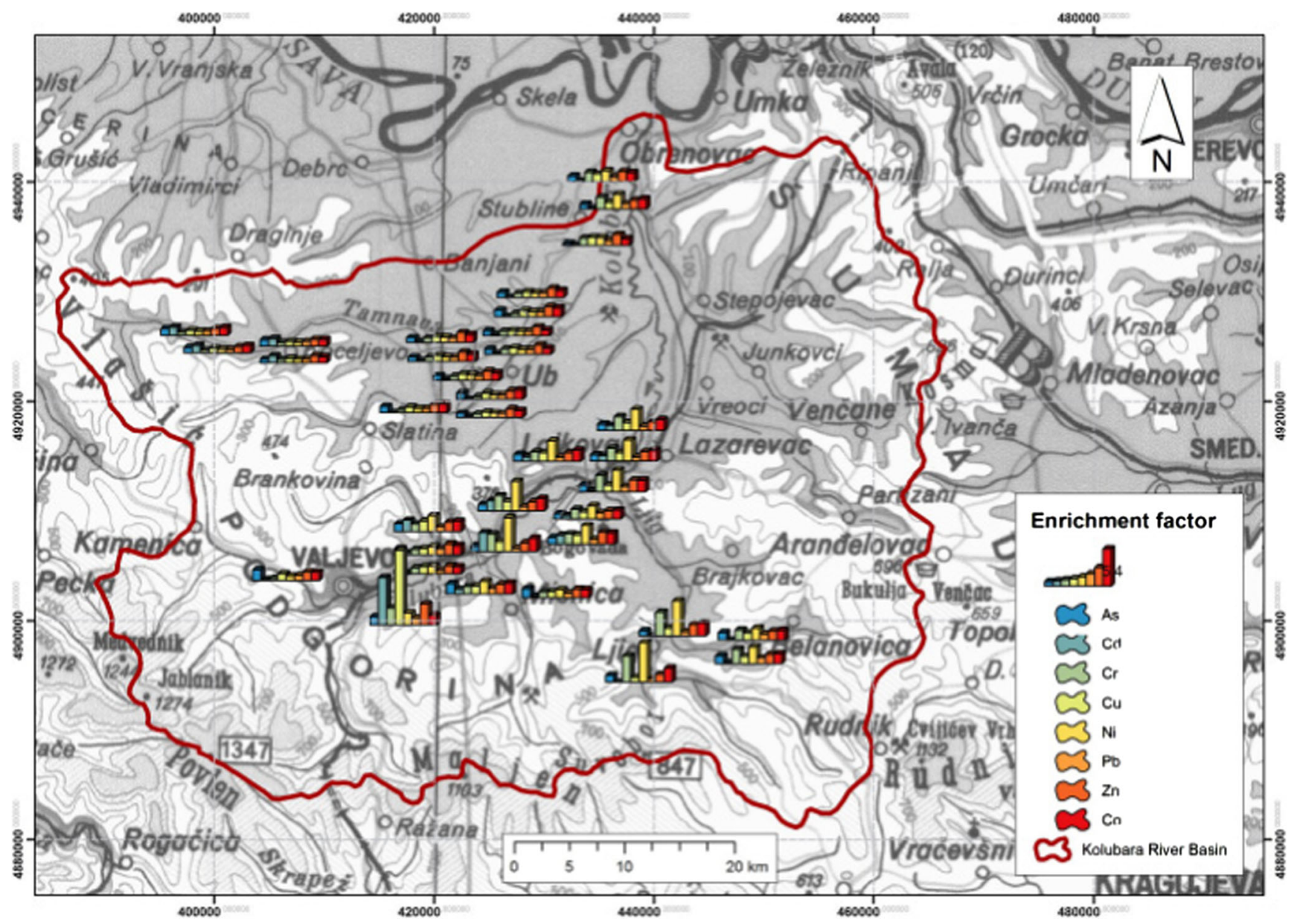

Fig. 4 Enrichment factor for soil 


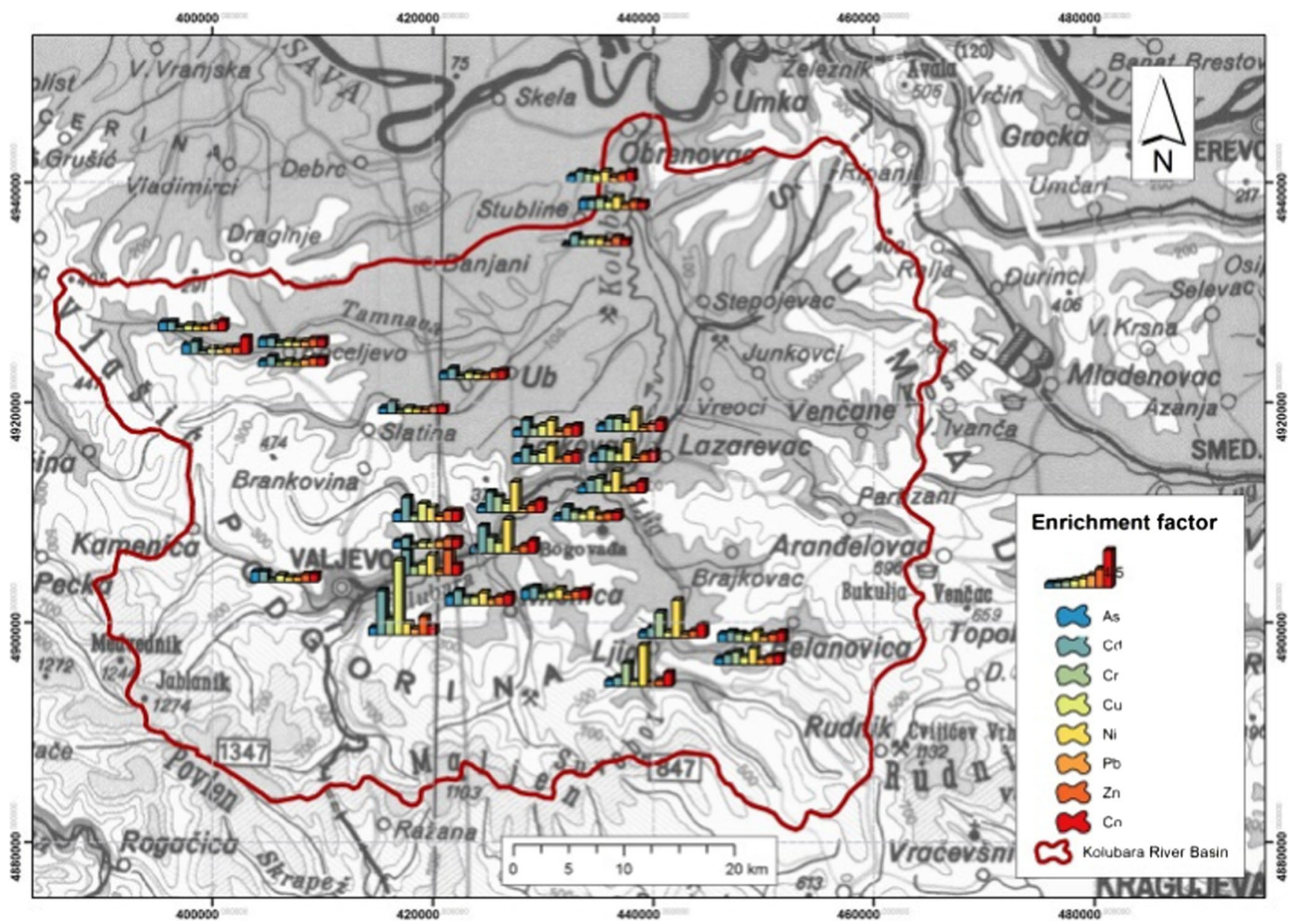

Fig. 5 Enrichment factor for flood sediment

was observed in the upper course of the Kolubara. $\mathrm{Pb}$ and As influence is most prevalent in the upper part of the Kolubara Basin, partially including areas in the upper course of the Kolubara (zone I), the entirety of zone III in the south-western part of the Basin, and partially zone IV, encompassing the River Ljig area. A similar spatial distribution for the influence of individual PTE upon locations was established for flood sediment (Figs. 6 and 7).

For most of the elements, PC-MLR analysis showed that the influence of factors not belonging to the major components is higher in flood sediment than soil, which is especially marked for As (Fig. 8). a

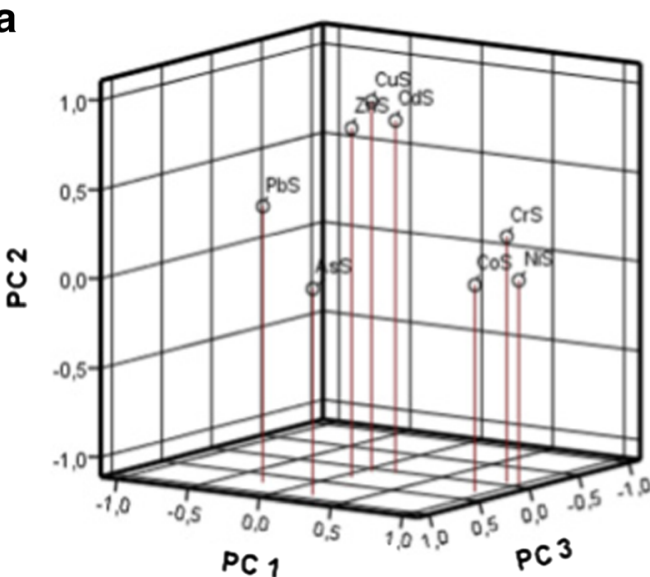

b

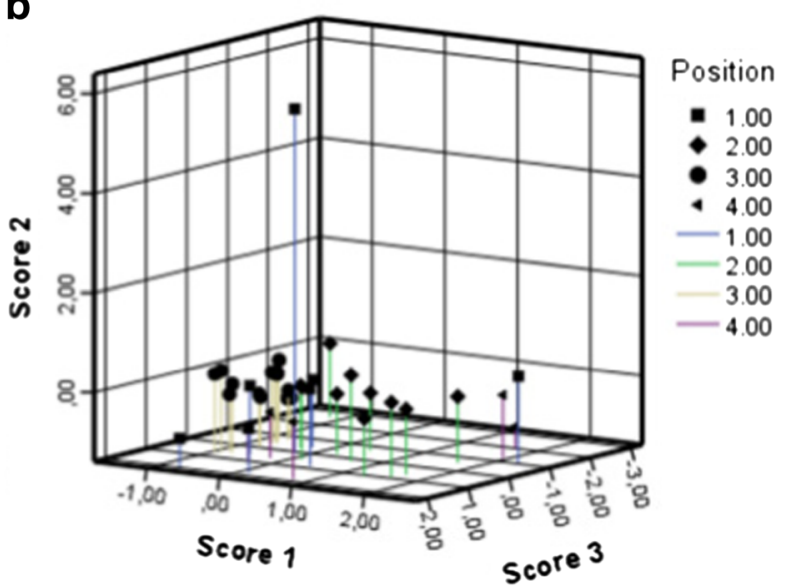

Fig. 6 a PCA loading plot for soil. b Graphic score for soil. 1, samples 1-7, zone I; 2, samples 8-17, zone II; 3, samples 18-31, zone III; 4, samples 3236; zone IV; MS, metal and metalloid in soil 

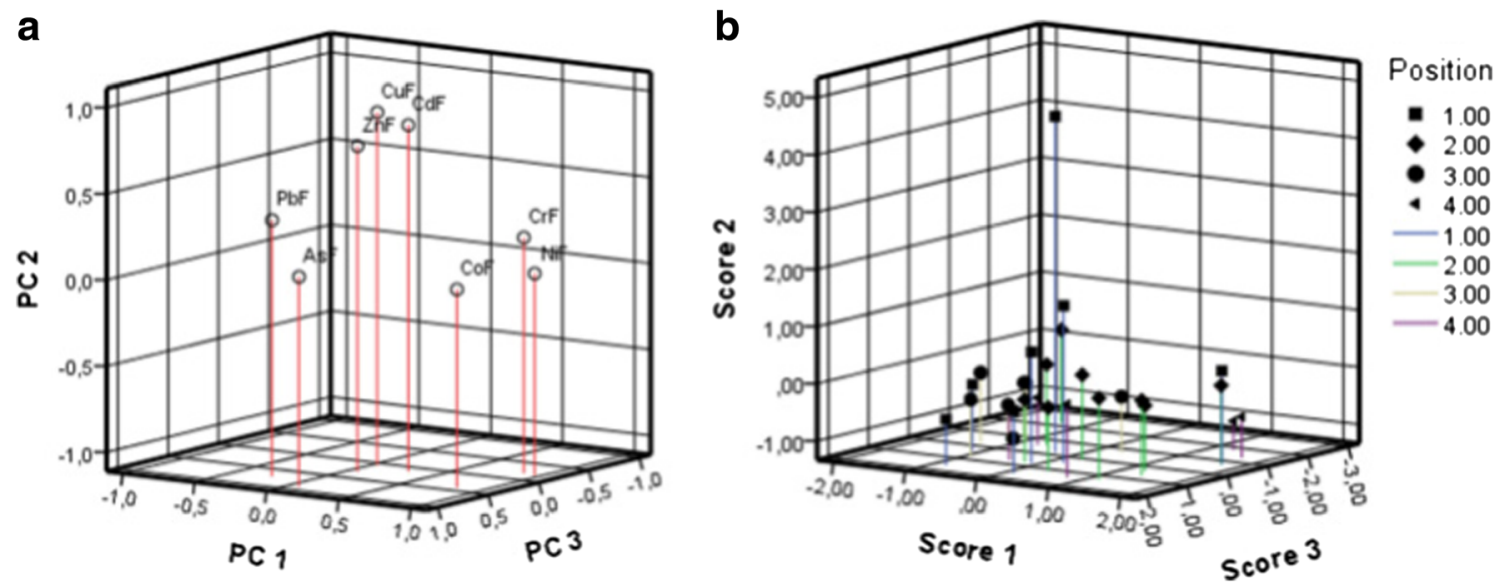

Fig. 7 a PCA loading plot for flood sediment. b Graphic score for flood sediment. 1, samples 1-7, zone I; 2, samples 8-17, zone II; 3, samples 18-31, zone III; 4, samples 32-36, zone IV; FS, metal and metalloid in flood sediment

\section{Discussion}

For the Kolubara Basin, the background value of As in soil was $10.30 \mathrm{mg} \mathrm{kg}^{-1}$ (based on 247 analyzed samples). The average value in world soils is $10 \mathrm{mg} \mathrm{kg}^{-1}$ (O’Neill 1995), while in Serbian soils, it is $11 \mathrm{mg} \mathrm{kg}^{-1}$ (Mrvic et al. 2009; Pavlović et al. 2017). Average As levels in the Kolubara sediments were $6.52 \mathrm{mg} \mathrm{kg}^{-1}$, which is within the range for the River Sava (4-10 $\mathrm{mg} \mathrm{kg}^{-1}$, Milačič et al. 2017) and considerably less than values for the Danube $\left(70 \mathrm{mg} \mathrm{kg}^{-1}\right.$, Comero et al. 2014).

The predominant influence of ore deposits can be clearly seen in the MLR analysis and is also reflected in the Ef, where almost a third of the samples are categorized as "minor impact" (Table 2 and Fig. 7). The prevalent influence of lead ore is clear on Mts. Maljen and Rudnik (Filipović 2005; Mrvic et al. 2009; Antić-Mladenović et al. 2017; Pavlović et al. 2017) as a source of $\mathrm{Pb}$ and also As (O’Neill 1995), which is confirmed by the highly significant positive correlation of these two elements in both soil and flood sediment in Table S3
(Electronic Supplementary Material). The spatial distribution of higher As levels is marked primarily in the upper course of the Kolubara, which is confirmed by PC analysis (Figs. 6 and 7) and Ef (Figs. 4 and 5). However, the anthropogenic influence is also noticeable at point 2 in Table S1 (Electronic Supplementary Material), downriver from Valjevo, most likely due to the influence of the metal industry (Krušik Holding Corporation, Valjevo) (Kabata-Pendias 2011). The evident increase in the influence of those factors not defined as significant in the MLRA on the As content in flood sediment results from increased As solubility in the redox conditions caused by flood water stagnation (Adriano 2002).

In world soils, the background value for $\mathrm{Cd}$ is $0.40 \mathrm{mg} \mathrm{kg}^{-1}$ (Berrow and Reaves 1984), while the average content in Serbian soils is $0.80 \mathrm{mg} \mathrm{kg}^{-1}$ (Mrvic et al. 2009). In the Kolubara Basin, background levels are in line with the global average, at $0.45 \mathrm{mg} \mathrm{kg}^{-1}$. Specificities relating to $\mathrm{Cd}$ were also observed in the investigated area: its relatively high solubility in sediments compared to other PTE (Mitchell et al. 2016) and its possible geochemical origin from $\mathrm{Zn}, \mathrm{Zn}-\mathrm{Pb}$, and $\mathrm{Pb}-\mathrm{Cu}-$
Fig. 8 Apportionment percentage of possible source types based on observed PTE concentrations. MS, metal and metalloid in soil; MF, metal and metalloid in flood sediment

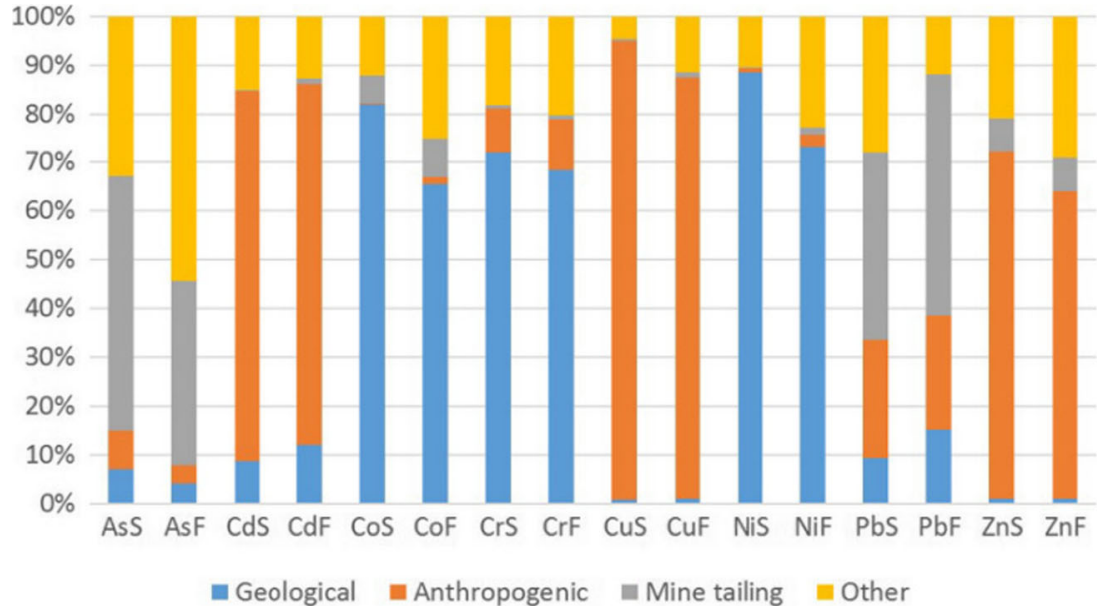


Zn mines (Adriano 2002), as well its anthropogenic origin related to the metal industry and urban areas (KabataPendias 2011). In our study, elevated Cd concentrations reflect an increase in Ef for soil and flood sediment from "no influence" to "minor influence," with the highest pseudototal content values established downriver from Valjevo (Supplementary 1), where the metal industry is located. According to PCA, point-source soil and sediment contamination in sample 2 (zone I) is related to this site. Obviously, the greatest impact of anthropogenic pollution was observed downriver from Valjevo, indicated by its significant correlation with $\mathrm{Zn}$ both in soil $\left(r=786^{* *}\right)$ and flood sediment $(r=$ $533^{* *}$ ) in Table S3 (Electronic Supplementary Material). The lower correlation between $\mathrm{Zn}$ and $\mathrm{Cd}$ in flood sediment is down to greater $\mathrm{Cd}$ solubility and its transport along the river course (Mitchell et al. 2016; Wei et al. 2016). Although the MLR analysis mainly indicates the anthropogenic origin of $\mathrm{Cd}$ (Fig. 8), its origin is also conditioned by natural sources from the boundaries of the Jadar block (Filipović 2005; Mrvic et al. 2009), which dictates the background of the Basin to a large extent. The extensive impact of anthropogenic factors on $\mathrm{Cd}$ content in sediment can be closely related to the TamnavaWest Field lignite mine in zone III (Fig. 7). Although Cd content in lignite is low (Pavlović et al. 2004), its high solubility (Mitchell et al. 2016; Wei et al. 2016) affects its overall content in flood sediment under specific flood conditionshence, the increase in the percentage of the "minor" Ef category, caused by the average $\mathrm{Cd}$ content in sediment rising $\left(0.60 \mathrm{mg} \mathrm{kg}^{-1}\right)$ compared to the determined background levels. However, compared to $\mathrm{Cd}$ content found in the sediment of Serbia's major rivers $\left(1.28-10.50 \mathrm{mg} \mathrm{kg}^{-1}\right.$ (Sakan et al. 2015), including the Sava (0.99 $\mathrm{mg} \mathrm{kg}^{-1}$, Vidmar et al. 2017) and the Danube (>3 $\mathrm{mg} \mathrm{kg}^{-1}$, Comero et al. 2014), the content in the Kolubara is low. The low content of $\mathrm{Cd}$ of anthropogenic origin indicates that this element is not a limiting factor for agricultural production after flood waters recede.

Average Co content in world soils is $10 \mathrm{mg} \mathrm{kg}^{-1}$ (Kabata-Pendias 2011), while the background value for the Kolubara Basin is $14.49 \mathrm{mg} \mathrm{kg}^{-1}$. In the flood sediment, the average value of $13.21 \mathrm{mg} \mathrm{kg}^{-1}$ is similar to background soil values and is towards the lower end of the established value range for levels in Serbian river sediment (8.22-36.2 mg kg${ }^{-1}$ ) (Sakan et al. 2015). Regardless of the very high percentage of samples in the category "slightly polluted" for Pi and "minor effect" for Ef (Table 2), in the PCA, cobalt is in the same cluster as $\mathrm{Cr}$ and $\mathrm{Ni}$ with most influence in PC1. Similarly, the MLR analysis and the mutual correlations of these three elements in Figs. 5 and 6 and Table S3 (Electronic Supplementary Material) clearly show the geological origin of Co (Anderson et al. 1973). Earlier studies pointed to sources of serpentine in the Mts. Rudnik and Maljen regions (Mrvic et al. 2009; Antić-Mladenović et al. 2017), where elevated Co concentrations were recorded in the upper course (zones 1 and IV), and partially in the lower course of the Kolubara, especially in the sediments, caused by its movement along the river course (Figs. 6 and 7).

Average $\mathrm{Cu}$ content for world soils is $30 \mathrm{mg} \mathrm{kg}^{-1}$ (Adriano 2002), but levels are lower in Serbian soils (22.24 $\mathrm{mg} \mathrm{kg}^{-1}$ ). The average $\mathrm{Cu}$ content in flood sediment was $21.14 \mathrm{mg} \mathrm{kg}^{-1}$, which is towards the lower end of the established value range for levels in Serbian river sediment (11.5-870 $\mathrm{mg} \mathrm{kg}^{-1}$ ) (Sakan et al. 2015) and for the Danube (28.3$193.7 \mathrm{mg} \mathrm{kg}^{-1}$ ) (Woitke et al. 2003). The Pi value for $\mathrm{Cu}$ shows that only in one sample were $\mathrm{Cu}$ concentrations found at the moderately polluted level. Considering the low background levels, the Ef reveals the somewhat greater impact of anthropogenic factors or an increased percentage of the "minor" Ef class (Table 1). Igeo also indicates that individual samples in the "moderately polluted" class are associated with point-source pollution in areas downriver of Valjevo due to the developed metal industry and city traffic (Adriano 2002). The PCA showed the crucial impact of anthropogenic factors, highlighting this point-source pollution. This was also confirmed by the MLR analysis with $\mathrm{Cu}$ content mostly influenced by anthropogenic factors. Its total content in soil and flood sediments indicates that the flooding did not affect the productive capacity of the studied agricultural soils.

The background $\mathrm{Ni}$ content in the Kolubara River Basin is $54.87 \mathrm{mg} \mathrm{kg}^{-1}$, which is similar to the world average (50 $\mathrm{mg} \mathrm{kg}^{-1}$, Adriano 2002). In the flood sediments, the somewhat higher concentrations were still within the range established for Serbian rivers (33.2-274 mg kg${ }^{-1}$ ) (Sakan et al. 2015) and for the Danube (23.2-89.8 mg kg-1, Woitke et al. 2003) but significantly higher than in the Sava at the confluence with the Kolubara (100-250 mg kg${ }^{-1}$, Vidmar et al. 2017). In our study, the increased solubility of $\mathrm{Ni}$ in serpentine compared to chromium (Quantina et al. 2008) probably resulted in its percentage in the first $\mathrm{Pi}$, Ef, and Igeo categories being lower. There is also a difference in the Ef for soil and flood sediment, with the percentage of the "no influence" Ef class higher for soil (42\%) than sediment (32\%). This is probably due to the high intensity erosion found in those areas with high Ni content (Belanovic-Simic et al. 2013), which under the influence of extreme precipitation is washed out into the river courses in the Kolubara Basin (Serbian Government Report on Floods, 2014). The PCA and MLR analysis showed that Ni content was mostly dependent on its geological origin, which is identical to $\mathrm{Co}$ and $\mathrm{Cr}$ and explains the very high significant correlations between these three elements in Table S2 Electronic (Supplementary Material) and Figs. 6, 7, and 8. Moreover, the action of $\mathrm{Ni}$ is most pronounced in areas characterized by higher $\mathrm{Cr}$ and $\mathrm{Co}$ levels in the upper part of the Kolubara River Basin (based on PCA, Supplementary 1). However, in areas of the lower part 
of the Kolubara, near Obrenovac (Supplementary 1), its content is also higher due to Ni-bearing clay minerals formed during the first stage of ultramafic rock weathering (Raous et al. 2013), which can be transported large distances by rivers (Lim et al. 2012). Although Ni is of geological origin, its increased solubility in changed oxido-redox conditions (Antić-Mladenović et al. 2017) can be a limiting factor in plant production in areas affected by flooding.

The background $\mathrm{Pb}$ value in the studied soil is $40 \mathrm{mg} \mathrm{kg}^{-1}$, which is more than in world soils $\left(10-30 \mathrm{mg} \mathrm{kg}^{-1}\right.$, Alloway 2013) but identical to average values for Serbian soils (Mrvic et al. 2009). Average $\mathrm{Pb}$ values for sediment are $17.7 \mathrm{mg} \mathrm{kg}^{-1}$, which is significantly less compared to Serbian river sediment (57.8-318 $\mathrm{mg} \mathrm{kg}^{-1}$, Sakan et al. 2015) and that in the Danube (18.2-85.0 mg kg-1, Woitke et al. 2003). However, its total levels, and the Pi, Ef, and Igeo values, were at the nonpolluted level, except for the Ef value in soil sample 2 (zone I), which is again affected by industry in Valjevo in Table S1 (Electronic Supplementary Material). Its high background level is mainly due to geological sources as $\mathrm{Pb}$ and As generally have the same origin, which is confirmed by the significant positive correlation between these two PTE in Table S3 (Electronic Supplementary Material), as well as the cluster formation with As in the PCA. The partial overlap with $\mathrm{Cu}, \mathrm{Zn}$, and $\mathrm{Cd}$, compared to the other component, indicates its slightly elevated content in the vicinity of Valjevo due to the anthropogenic impact. The MLR analysis indicates the high impact of anthropogenic factors on its content, but PC1 and PC3 suggest that partial geological origin predominates in sediment, indicating historical $\mathrm{Pb}$ pollution, which resulted in the percentage in the "unpolluted" EF class for flood sediment being higher than for soil. The absence of any correlation between $\mathrm{Pb}$ and $\mathrm{Ni}$, and $\mathrm{Pb}$ and $\mathrm{Cr}$, implies that they are not of common origin, but the proximity of their sources has led to a large proportion of $\mathrm{PC} 1$ in recognizing its origin in the MLR analysis.

The background $\mathrm{Zn}$ value in the Kolubara River Basin is $69 \mathrm{mg} \mathrm{kg}^{-1}$, which is similar to the average for the Earth's crust (Krauskopf 1979), while the value established for flood sediment $\left(55.84 \mathrm{mg} \mathrm{kg}^{-1}\right)$ is within that range but much lower than the values for the Danube (99-398 $\mathrm{mg} \mathrm{kg}^{-1}$, Woitke et al. 2003). The Pi and Igeo values fall into the lowest class, except for the $\mathrm{Ef}$ for soil. The common origin of $\mathrm{Zn}$ and $\mathrm{Pb}$ was established by their correlation in Table S3 (Electronic Supplementary Material), while the natural source of these elements has a lower Ef in flood sediment than in soil. However, in the PCA, its content is closely related to $\mathrm{Cu}$ and $\mathrm{Cd}$ and greatly influenced by anthropogenic sources. Such a differentiation is the result of industry in Valjevo, including the combustion of fossil fuels (Adriano 2002). The mine's influence was established by the MLRA, i.e., the relatively high percentage of the third component (about 7\%) in soil and flood sediment, as well as its significant correlation with $\mathrm{Pb}$ in Table S3 (Electronic Supplementary Material).

\section{Conclusions}

This study found that individual levels of all the harmful microelements were below the MAC for PTE for agricultural soil except for $\mathrm{Ni}, \mathrm{Cr}$, and $\mathrm{Cu}$, with only $\mathrm{Cu}$ concentrations exceeding the MAC in a single soil and flood sediment sample.

For most of the elements, individual indicators of the impact of PTE on soil and flood sediment contamination show they have no impact or only minor impact, with only individual cases falling into higher classes, indicating the absence of pollution in the Kolubara River Basin. Ni is in the higher categories for flood sediment, which was directly reflected in Igeo and relatively few samples are in the "without influence" class. This results from its solubility in the changed oxido-redox conditions. However, given the total content, in these conditions, only $\mathrm{Ni}$ may be a limiting factor in plant production in the Kolubara River Basin.

The geological origin of $\mathrm{Ni}, \mathrm{Cr}, \mathrm{Co}$, and the mixed (both geological and anthropogenic) origin of $\mathrm{As}$ and $\mathrm{Pb}$ was clearly defined, with their levels mainly related to the nature of the rocks in the mountains in the peripheral parts of the river basin, where their natural deposits are found. However, $\mathrm{Cd}, \mathrm{Zn}$, and $\mathrm{Cu}$ are mostly of anthropogenic origin arising from cities with a developed metal industry (Valjevo and Obrenovac).

Based on all these indicators, the 2014 flooding did not result in changes to the state of PTE; instead, the observed changes were already a part of the natural soil formation processes in the basin with minimal anthropogenic impact. Therefore, the floods did not result in significant soil pollution in the Kolubara River Basin and the soil is safe for agricultural production.

Acknowledgments This work was supported by the Ministry of Education, Science and Technological Development of the Republic of Serbia, grant. no. 173018, III 43007, TR 37006.

\section{References}

Adriano DC (2002) Trace elements in terrestrial environments. Biogeochemistry, bioavailability, and risk of metals. SpringerVerlag, Berlin

Alexander EB, Coleman RG, Keeler-Wolfe T (2007) Serpentine geoecology of western North America: geology, soils, and vegetation. Oxford University Press, Cary

Alloway JB (2013) Heavy metals in soil. Trace metals and metalloids in soil and their bioavailability. Springer, Dordrecht

Anderson AJ, Meyer DR, Mayer FK (1973) Heavy metal toxicities: levels of nickel, cobalt and chromium in the soil and plants associated with visual symptoms and variation in growth of an oat crop. Aust J Agrie Res 24(4):557-571. https://doi.org/10.1071/ AR9730557

Antić-Mladenović S, Frohne T, Kresović M, Stärk HJ, Tomić Z, Ličina V, Rinklebe J (2017) Biogeochemistry of $\mathrm{Ni}$ and $\mathrm{Pb}$ in a periodically flooded arable soil: fractionation and redox-induced (im)mobilization. J Environ Manag 186:141-150 
Bates BC, Kundzewicz ZW, Wu S, Palutikof JP (2008) Climate change and water. Technical paper of the intergovernmental panel on climate change. IPCC Secretariat, Geneva

Belanovic-Simic S, Perovic V, Vidojevic D, Kostadinov S, Knezevic M, Kadovic R, Kosanin O (2013) Assessment of soil erosion intensity in Kolubara District, Serbia. Fresenius Environ Bull 22(5a):1556-1563

Berrow ML, Reaves GA (1984) Background levels of trace elements in soils. In: Proceedings of the International Conference Of Environmental Of Contamination. CEP Consultants Ltd., Edinburgh, pp 333-340

Brooks RR (1987) Serpentine and its vegetation. A multidisciplinary approach. Dioscorides Press, Portland

Cabral Pinto MMS, Ferreira da Silva EA, Silva MMVG, Melo-Gonçalves P, Candeias C (2014) Environmental risk assessment based on highresolution spatial maps of potential toxic elements sampled on stream sediments of Santiago, Cape Verde. Geosciences 4(4):297315. https://doi.org/10.3390/geosciences4040297

Cakmak D, Saljnikov E, Mrvic V, Jakovljevic M, Marjanovic Z, Sikiric B, Maksimovic S (2010) Soil properties and trace elements contents following 40 years of phosphate fertilization. J Environ Qual 39(2): 41-547

Cao Y, Zhang D, Shen F, Wang J, Faladysz J, Jarzynska G, Li W, Wang K (2013) As, Cd, Cr, Hg, Ni and $\mathrm{Pb}$ in soil from eastern slope of Mt. Gongga, Eastern Tibet, China. Adv J Food Sci Technol 5(6):775-782

Comero S, Vaccaro S, Locoro G, De Capitani L, Gawlik BM (2014) Characterization of the Danube River sediments using the PMF multivariate. Chemosphere 95:329-335. https://doi.org/10.1016/j. chemosphere.2013.09.028

Du Laing G, Rinklebe J, Vandecasteele B, Meers E, Tack FMG (2009) Trace metal behaviour in estuarine and riverine floodplain soils and sediments: a review. Sci Total Environ 407(13):3972-3985. https:// doi.org/10.1016/j.scitotenv.2008.07.025

Đukanović D (2000) Climate of the Valjevo region. Ed. Valjevo Assembly, Valjevo, pp 1-377 (in Serbian)

Erftemeijer PLA, Riegl B, Hoeksema BW, Todd PA (2012) Environmental impacts of dredging and other sediment disturbances on corals: a review. Mar Pollut Bull 64(9):1737-1765. https://doi. org/10.1016/j.marpolbul.2012.05.008

Filipović I (2005) Spatial distribution of geological resources in northwestern Serbia (Jadar block terrane) and its relation to tectonic structures. Annales Géologiques de la Péninsule Balkanique 66:17-20

Geolis, Geological Information System of Serbia (2010) Osnovne geološke karte Srbije 1:100000.Zavod za geološka i geofizička istraživanja Beograd 1959-1966. http://geoliss.mre.gov.rs/

Giri S, Singh AK, Mahato MK (2017) Metal contamination of agricultural soils in the copper mining areas of Singhbhum shear zone in India. J Earth Syst Sci 126:49

Green C, Dieperink C, Ek K, Hegger DLT, Pettersson M, Priest S, Tapsell S (2013) Flood risk management in Europe: the flood problem and interventions (report no D1.1.1), STAR-FLOOD Consortium, Utrecht

Guo Y, Huang CC, Pang J, Zha X, Li X, Zhang Y (2014) Concentration of heavy metals in the modern flood slackwater deposits along the upper Hanjiang River valley, China. Catena 116:123-131. https:// doi.org/10.1016/j.catena.2013.12.019

Hutchinson SM, Rothwell JJ (2008) Mobilisation of sediment-associated metals from historical $\mathrm{Pb}$ working sites on the River Sheaf, Sheffield, UK. Environ Pollut 155(1):61-71. https://doi.org/10. 1016/j.envpol.2007.10.033

Kabata-Pendias A (2011) Soil and plants. CRC Press Taylor \& Francis Group, Boca Raton

Krauskopf KB (1979) Introduction to geochemistry, 2nd edn. McGrawHill, New York

Lauer J (2008) Flooding impacts on crown growth and yield, University of Wisconsin. Field Crops 28:49-56
Lim WY, Aris AZ, Zakaria MP (2012) Spatial variability of metals in surface water and sediment in the Langat River and geochemical factors that influence their water-sediment interactions. Sci World J 1-14. https://doi.org/10.1100/2012/652150

Liu J, Wang J, Chen Y, Xie X, Qi J, Lippold H, Luo D, Wang C, Su L, He L, Wu Q (2016) Thallium transformation and partitioning during $\mathrm{Pb}$ -Zn smelting and environmental implications. Environ Pollut 212: 77-89. https://doi.org/10.1016/j.envpol.2016.01.046

Martínez-Santos M, Probst A, García-García J, Ruiz-Romera E (2015) Influence of anthropogenic inputs and a high-magnitude flood event on metal contamination pattern in surface bottom sediments from the Deba River urban catchment. Sci Total Environ 514:10-25. https://doi.org/10.1016/j.scitotenv.2015.01.078

Massoura ST, Echevarria G, Becquer T, Ghanbaja J, Leclerc-Cessac E, Morel J (2006) Control of nickel availability by nickel bearing minerals in natural and anthropogenic soils. Geoderma 136(1-2):28-37. https://doi.org/10.1016/j.geoderma.2006.01.008

Milačič R, Zuliani T, Vidmar J, Oprčkal P, Ščančar J (2017) Potentially toxic elements in water and sediments of the Sava River under extreme flow events. Sci Total Environ 605-606:894-905. https:// doi.org/10.1016/j.scitotenv.2017.06.260

Mitchell N, Ramos Gomez MS, Guerrero Barrera AL, Yamamoto Flores L, Flores de la Torre JA, Avelar Gonzalez FJ (2016) Contaminated soils and sediments near mining sites in Aguascalientes, Mexico. Bull Environ Contam Toxicol 97(2):216-224. https://doi.org/10. 1007/s00128-016-1820-9

Mrvić V, Zdravković M, Sikirić B, Čakmak D, Kostić-Kravljanac L (2009) Toxic and dangerous elements in soil. In: Mrvić et al (ed) Fertility and content of toxic and dangerous materials in soil of Central Serbia Institute of Soil Science Belgrade, pp 75-134 (in Serbian)

Mrvić V, Kostić-Kravljanac L, Čakmak D, Sikirić B, Brebanović B, Perović V, Nikoloski M (2011) Pedogeochemical mapping and background limit of trace elements in soils of Branicevo Province (Serbia). J Geochem Explor 109(1-3):18-25. https://doi.org/10. 1016/j.gexplo.2010.09.005

Mrvić V, Antonović G, Čakmak D, Perović V, Maksimović S, Saljnikov E, Nikoloski M (2013) Pedological and pedogeochemical map of Serbia. The 1st International Congress on Soil Science XIII National Congress in Soil Science, September 23rd-26th, Belgrade, Serbia. 93-105. UDC: 502.55:631.452

N'guessan YM, Probst JL, Bur A, Probst A (2009) Trace elements in stream bed sediments from agricultural catchments (Gascogne region, S-W France): where do they come from? Sci Total Environ 407(8):2939-2952. https://doi.org/10.1016/j.scitotenv.2008.12.047

O’Neill P (1995) Cadmium. In: Alloway BJ (ed) Heavy metals in soils. Chapman and Hall, London, pp 105-119

Pavlović P, Mitrović M, Djurdjević L (2004) An ecophysiological study of plants growing the fly ash deposits from the 'Nikola Tesla-A' thermal power station in Serbia. Environ Manag 33(5):654-663. https://doi.org/10.1007/s00267-004-2928-y

Pavlović P, Kostić N, Karadžić B, Mitrović M (2017) The soils of Serbia. Springer Science+Business Media, Dordrecht. https://doi.org/10. 1007/978-94-017-8660-7

Petrović A, Kostadinov S, Dragićević S (2014) The inventory and characterization of torrential flood phenomenon in Serbia. Pol J Environ Stud 23(3):823-830

Quantina C, Ettler V, Garniera J, Sebek O (2008) Sources and extractability of chromium and nickel in soil profiles developed on Czech serpentinites. C R Geoscience 340(12):872-882. https://doi.org/10. 1016/j.crte.2008.07.013

Raous S, Echevarria G, Sterckeman T, Hanna K, Thomas F, Martins ES, Becquer T (2013) Potentially toxic metals in ultramafic mining materials: identification of the main bearing and reactive phases. Geoderma 192:111-119. https://doi.org/10.1016/j.geoderma.2012. 08.017 
Reddy MS, Basha S, Sravan Kumar VG, Joshi HV, Ramachandraiah G (2004) Distribution, enrichment and accumulation of heavy metals in coastal sediments of Alang-Sosiya ship scrapping yard. India. Mar Pollut Bull 48(11-12):1055-1059. https://doi.org/10.1016/j. marpolbul.2003.12.011

Regulation of the Government of the Republic of Serbia on the program of systematic monitoring of soil quality, indicators for the assessment of land degradation and methodology for remediation programs (2010) Government Gazette of the Republic of Serbia. SG RS88/2010: 226-231

Regulations of the Ministry of Agriculture, Forestry and Water management of the Republic of Serbia on allowed amounts of hazardous and noxious substances in agricultural soil and water for irrigation and methods for their testing (1994) Government Gazette of the Republic of Serbia. SG RS 23/94: 553-554

Reimann C, Filzmoser P, Garrett RG (2005) Background and threshold: critical comparison of methods of determination. Sci Total Environ 346(1-3):1-16. https://doi.org/10.1016/j.scitotenv.2004.11.023

Roca N, Pazos MS, Bech J (2012) Background levels of potentially toxic elements in soils: a case study in Catamarca (a semiarid region in Argentina). Catena 92:55-66. https://doi.org/10.1016/j.catena.2011. 11.009

Sakan S, Dević G, Relić D, Anđelković I, Sakan N, Đorđević D (2015) Environmental assessment of heavy metal pollution in freshwater sediment, Serbia. Clean Soil Water Air 43(6):794-966

Santos-Araujo SN, Alleoni LRF (2016) Concentrations of potentially toxic elements in soils and vegetables from the macroregion of São Paulo, Brazil: availability for plant uptake. Environ Monit Assess 188(2):92. https://doi.org/10.1007/s10661-016-5100-2

Schiff KC, Weisberg SB (1999) Iron as a reference element for determining trace metal enrichment in Southern California coastal shelf sediments. Mar Environ Res 48(2):161-176. https://doi.org/10.1016/ S0141-1136(99)00033-1

Serbian Government Reports on Floods (2014) http://reliefweb.int/report/ serbia/serbia-floods-2014
SPSS Statistics for Windows, version 21 (SPSS Inc., Chicago, Ill., USA), about SPSS Inc. http://www.spss.com.hk/corpinfo/history.htm. Accessed 21 Sept 2017

Sterckeman T, Douay F, Proix N, Fourrier H, Perdrix E (2002) Assessment of the contamination of cultivated soils by eighteen trace elements around smelters in the North of France. Water Air Soil Pollut 135(1/4):173-194. https://doi.org/10.1023/A: 1014758811194

Summer JK, Wade LD, Engle VD, Malaeb ZA (1996) Normalization of metal concentrations in estuarine sediments from the Gulf of Mexico. Estuaries 19:581-594

U.S. Environmental Protection Agency (1996) Method 3050B. Acid digestion of sediments, sludges, and soils revision 2

Vidmar J, Zuliani T, Novak P, Drinčić A, Ščančar J, Milačič R (2017) Elements in water, suspended particulate matter and sediments of the Sava River. J Soils Sediments 17(7):1917-1927. https://doi.org/ 10.1007/s11368-016-1512-4

Wei X, Han L, Gao B, Zhou H, Wan X (2016) Distribution, bioavailability, and potential risk assessment of the metals in tributary sediments of Three Gorges Reservoir: the impact of water impoundment. Ecol Indic 61(2):667-675. https://doi.org/10.1016/j.ecolind.2015.10.018

Woitke P, Wellmitz J, Helm D, Kube P, Lepom P, Litheraty P (2003) Analysis and assessment of heavy metal pollution in suspended solids and sediments of the River Danube. Chemosphere 51(8): 633-642. https://doi.org/10.1016/S0045-6535(03)00217-0

WRB (2006) World Reference Base for Soil Resources. Food and Agriculture Organization of the United Nations, Rome

Xu Y, Sun Q, Yi L, Yin X, Wang A, Li Y, Chen J (2014) The source of natural and anthropogenic heavy metals in the sediments of the Minjiang River estuary (SE China): implications for historical pollution. Sci Total Environ 493:729-736. https://doi.org/10.1016/j. scitotenv.2014.06.046

Yin S, Lv HJ, Guo YX, Huang WH, Gang L (2013) An analysis of surface soil of city on levels of pollution based on Nemerow index and Geoaccumulation index. China Academic Journal Electronic Publishing House, CNKI, pp 698-701 